\title{
光応答性分散剂によるカーボンナノチューブ分散技術の高度化 Photofunctional Dispersants for Single-Walled Carbon Nanotubes
}

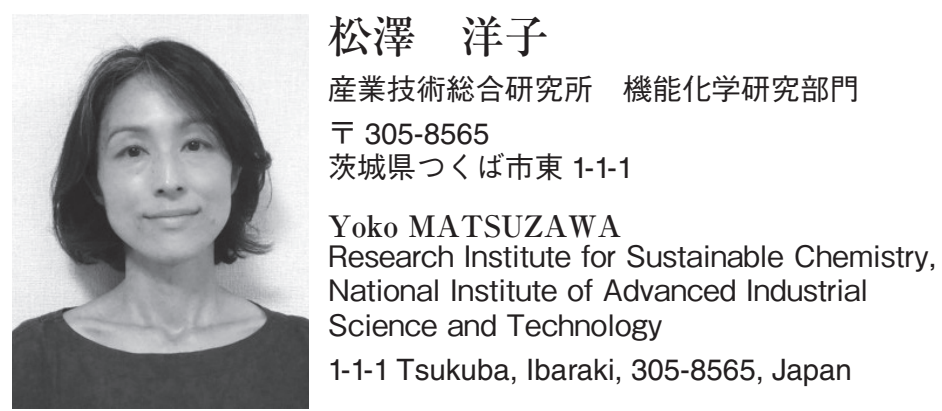

論文要旨：単層カーボンナノチューブ（SWCNT）はその魅力的な性質をデバイス応用することが期待さ れているナノ炭素材料である。しかしながら, SWCNT は溶解性にそしく，このことが応用への妨げになっ ている。この課題を解決する道筋の一つとして, 我々はSWCNT 表面の物性を分子の吸脱着を利用して制 御することを試みた。SWCNT のグラファイト表面と効率的に相互作用できるように, 複数の芳香環を光反 応する官能基で繋ぎ，光照射前後での SWCNT 表面への（分子構造による）親和性変化を利用した。この 光応答性分散剤はSWCNT を非常に効率的に分散することができ，光照射で簡単に外すことができる。こ の光応答性分散剂をつかって得られた分散液に, 超遠心操作と光照射を組み合わせると, 市販の SWCNT を精製することができ，また，調製した分散液で製膜後にマスク露光すると微細加工薄膜を作製することも できた。

\begin{abstract}
Single-walled carbon nanotubes (SWCNTs) have attracted a lot of attention as a result of their various applications, for instance, transistors, supercapacitors, sensors and so on. However, the industrial applications of SWCNTs have been hindered by their insolubility in many solvents. In order to improve their handling processes, we have investigated an excellent and photochemically tunable dispersant for SWCNTs, based on photoreaction of the dispersant in aqueous solution. The dispersant can be utilized in some application fields of SWCNTs. By the combining procedure, high-speed centrifugation using the dispersant, we have demonstrated a new purification method for SWCNTs without destroying the intrinsic SWCNT structures. Photopatterned SWCNT thin films are easily fabricated by adsorption/desorption processes of the dispersant in solid films.
\end{abstract}

Key words: photoisomerization, stilbene, molecular electrorite, adsorption/desorption

\section{1 はじめに}

単層カーボンナノチューブ（SWCNT）は，その優れ た特性を活かし，部材として工業的に利用することを望 まれているナノ炭素材料の一つである。しかしながら, 強い分子間力により凝集しやすいため, デバイス加工や 媒体への分散・複合化が難しい。デバイスにおいて SWCNT の機能を十分に発揮させるためには, 繊維状の SWCNTをなるべく破損少なくよくほぐした状態で加工

連絡者：松澤 洋子

E-mail : yoko-matsuzawa@aist.go.jp
しなくてはならない。インク化等の加工技術は, SWCNTを活用していくための重要な要素技術である (Fig. 1)。これまでに, 数多くの界面活性剤や高分子が SWCNTの分散剤として報告されてきた。しかしながら， 自らのミセル形成によって SWCNTを可溶化する界面 活性剤は, 分散に必要とする量がSWCNTに対して過 剰（重量比で数十倍等）であったり, SWCNTに多点吸 着することで分散を促す高分子の場合は, 分散後に除去 することが難しく, 付着したままの高分子は最終的に不 純物として作用し, SWCNTの優れた特性に悪影響を及 ぼすことが知られている。SWCNTを有効に活用してい 


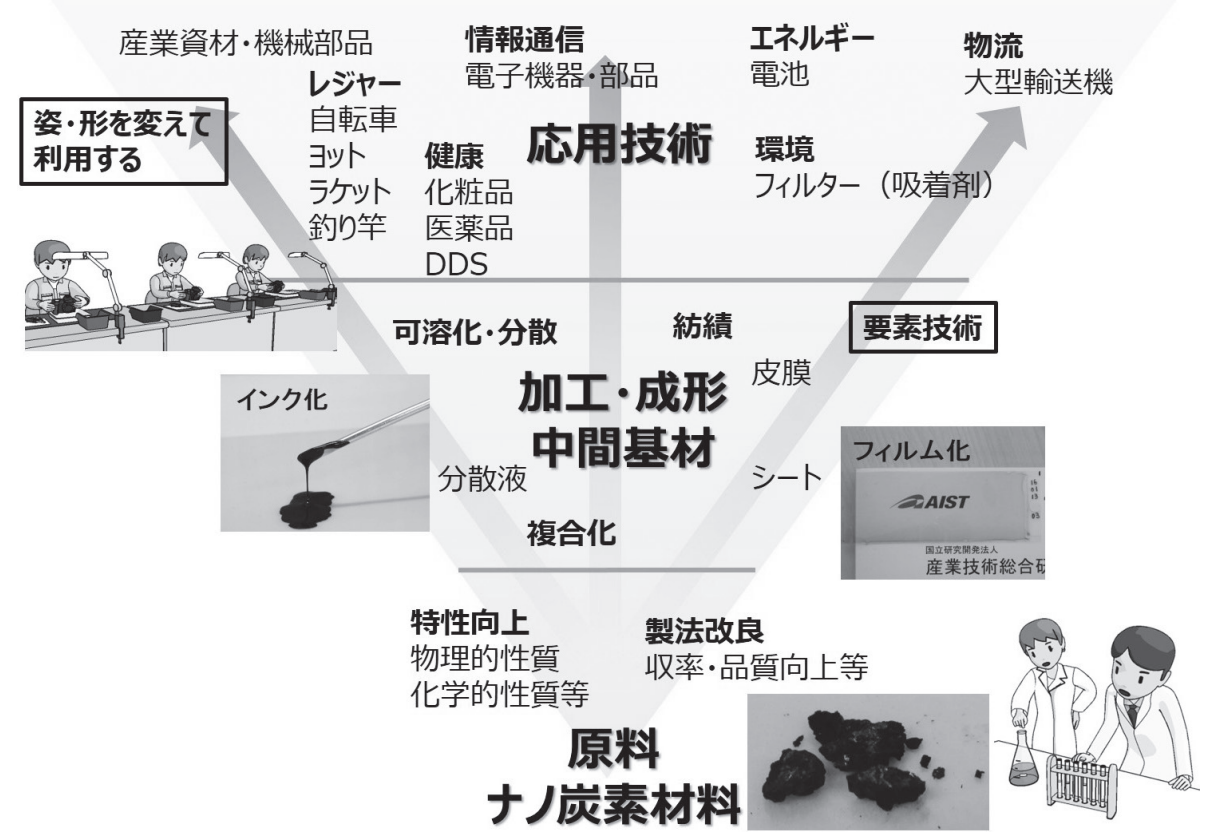

Fig. 1 SWCNT をとりまく技術的俯瞰図

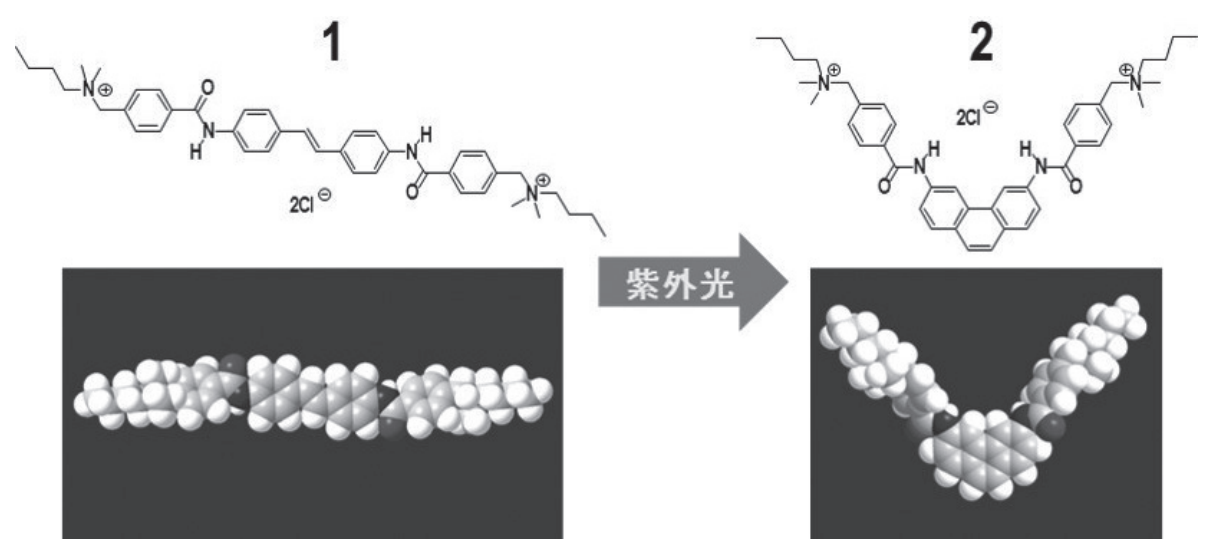

Fig. 2 設計合成した光応答性分散剂

くためには, 分散技術の高度化, 分散剤の高度化が望ま れていた。

本稿では, このような課題を有機合成・有機光化学・ コロイド界面化学の視点から解決すべく取り組んだ研究 を紹介する。

\section{2 分子設計の指針 ${ }^{11}$}

我々は, SWCNT 分散技術の高度化を目指し, (1)少量 の添加で効果的に分散することができ，なおかつ(2)外部 刺激により SWCNT を破損することなく剥がすことが できる，新しいコンセプトをもつSWCNT 分散剤の開 発を目指した。SWCNTのグラファイト表面と良好に相 互作用させるために, 複数の芳香環を平面に並べた剛直 な構造を分子の基本骨格とした（Fig. 2)。そして，今後 の応用展開も見据え, 外部刺激には指向性の高い刺激で
ある『光』を選択し, 光に応答する官能基（スチルベン） を組み込んた（化合物 1)。光照射によって分子構造が 劇的に変化し（スチルベン $\rightarrow$ スナンスレン）, SWCNT 表面との親和性がそしくなった分散剂（化合物 2）がSWCNT 表面から自発的に剥がれることを利用し た分散制御を試みた。

\section{3 光応答性分散剤の物性評価}

\section{$3 \cdot 1$ 分散性評価}

Fig. 2 に示すように，化合物 1 は SWCNT のグラファ イト状表面に効率的に物理吸着し, SWCNT 同士に分散 を促す斥力が働くようにするため，複数の芳香環をアミ ド結合を介してつなげた分子構造をしている。アミド結 合を用いることで分子の剛直性が増し, 芳香環が同一平 面上に並ぶため, SWCNT 表面と効果的に $\pi-\pi$ 相互作用 
することができる。そして，化合物 1 は末端が 4 級アン モニウム塩であるため水によく溶け，ミセル形成をする ことなく単独でSWCNT 表面に吸着することができ る。そして，この分子に覆われたSWCNTは 4 級アン モニウム基の働きにより正の電荷を帯び (約 $+60 \mathrm{mV})$, SWCNT の親水性の向上と静電反発により水への優れた 分散性／孤立分散性を促すことができる。

SWCNT 水分散液は, SWCNT と化合物 1 を水に混合 したあと, バス型超音波やホーン型破砕機等を利用して 分散を促す。市販のSWCNTに含まれる不純物（アモ ルファスカーボンや金属粒子）や充分に分散できていな いSWCNT等を遠心操作により除き，上澄み液を用い て各種分光装置（UV-Vis-NIR 吸収スペクトル，ラマン 散乱スペクトル, 近赤外発光スペクトル等) やモルフォ ロジー観察（AFM，SEM 等）することで分散性を評価 した。これら測定結果より, SWCNTは化合物 1 によっ て充分ほぐされ，孤立分散した状態で水中に分散してい ることがわかった。

さて, SWCNTは製造方法によって径や長さに多様性 があることが知られている。従来の界面活性剤はミセル を形成してSWCNTを包み込み可溶化させるため, そ の溶解性はSWCNT の径や長さに影響を受けやすい。 しかし, 化合物 1 はSWCNTに直接吸着してSWCNT 表面の溶媒への親和性を増加させて分散を促すため, そ の作用はSWCNTの径や長さに影響されることはな い。さらに，グラファイト状の表面を有するナノ粒子で ある多層カーボンナノチューブ, カーボンブラック等も, 化合物 1 はこれらの表面に効率的に吸着して親水性を付 与し，効果的に分散することができる。

\section{$3 \cdot 2$ 光による分散制御}

化合物 1 は，水中でほぼ等量的に光反応することを UV-vis 吸収スペクトルと NMR スペクトル測定によっ
て確認した。つづいて，化合物 1 を用いて作成した SWCNT 水溶液に光照射を行うと, 分散剤の光反応によ り分散性を失ったSWCNT が凝集・沈殿することがわ かった（Fig. 3）。SWCNT が沈殿した溶液には，スチル ベンの光反応により生成するフェナンスレン由来の蛍光 がみられ, SWCNT 存在下でも化合物 1 の光反応は妨げ られることなく充分に進行し, SWCNTの分散制御に作 用することがわかった。光の作用で屈曲した構造になっ た化合物 2 がSWCNTを分散しない, すなわち相互作 用しないことは, 予め光反応させて得られた化合物 2 に は, SWCNTを分散しないことから確認している。分子 構造の違いが分散制御の重要なファクターとなってい る。

\section{4 光応答性分散剂の応用}

さて，我々が開発した光の作用で剥がすことの出来る 分散剤を使った応用例をいくつか紹介する。

\section{4・1 SWCNT の精製 ${ }^{2)}$ (Fig. 4 上)}

市販されているSWCNT の多くは, 製造過程で生じ る副生成物（アモルファスカーボン）や，原料（触媒金 属）由来の金属粒子を多量に含んでいる。精製するため には強酸を使用して不純物を分解除去する手法等が知ら れているが, 強酸の使用はSWCNT の構造を劣化させ てしまう場合も多い。光応答性分散剂と超遠心（約 10 万g）分離を組み合わせると, SWCNT の構造を傷める ことなく精製できることを見出した。まず，化合物 1 を 用いて調製したSWCNT 分散液を超遠心操作すること で,アモルファスカーボンや金属粒子を除去する。その 後光照射して分散剂を外し，沈殿したSWCNTを精製 されたSWCNTとして回収することができる。この沈 殿したSWCNTと精製前のSWCNT, そして分散剂が 付着して溶解性の向上したSWCNTの熱重量分析を行

\section{•分散剤の光異性化を利用した, CNTの分散制御技術}

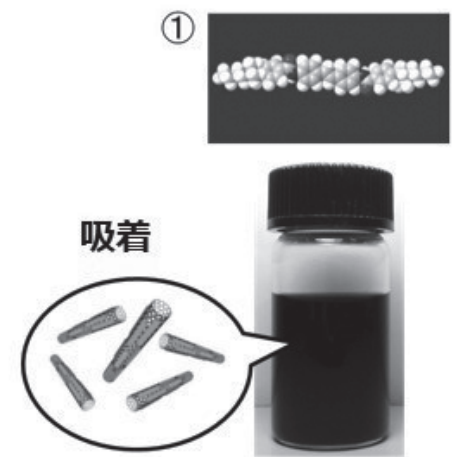

CNT分散水溶液

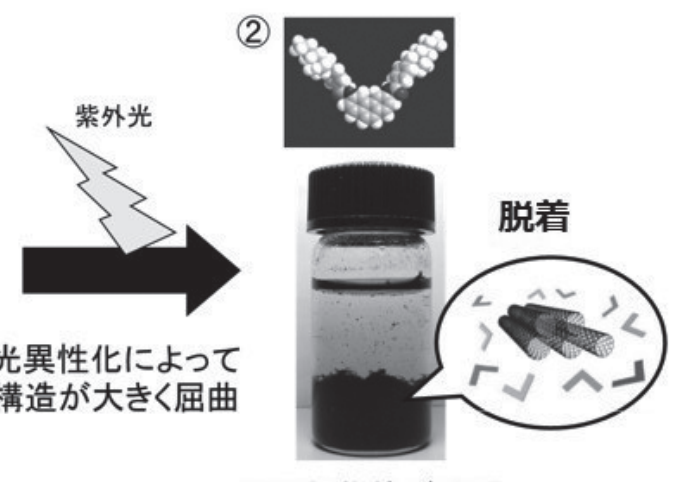

CNT凝集体が沈殿

Fig. 3 SWCNT の分散性を光で制御 


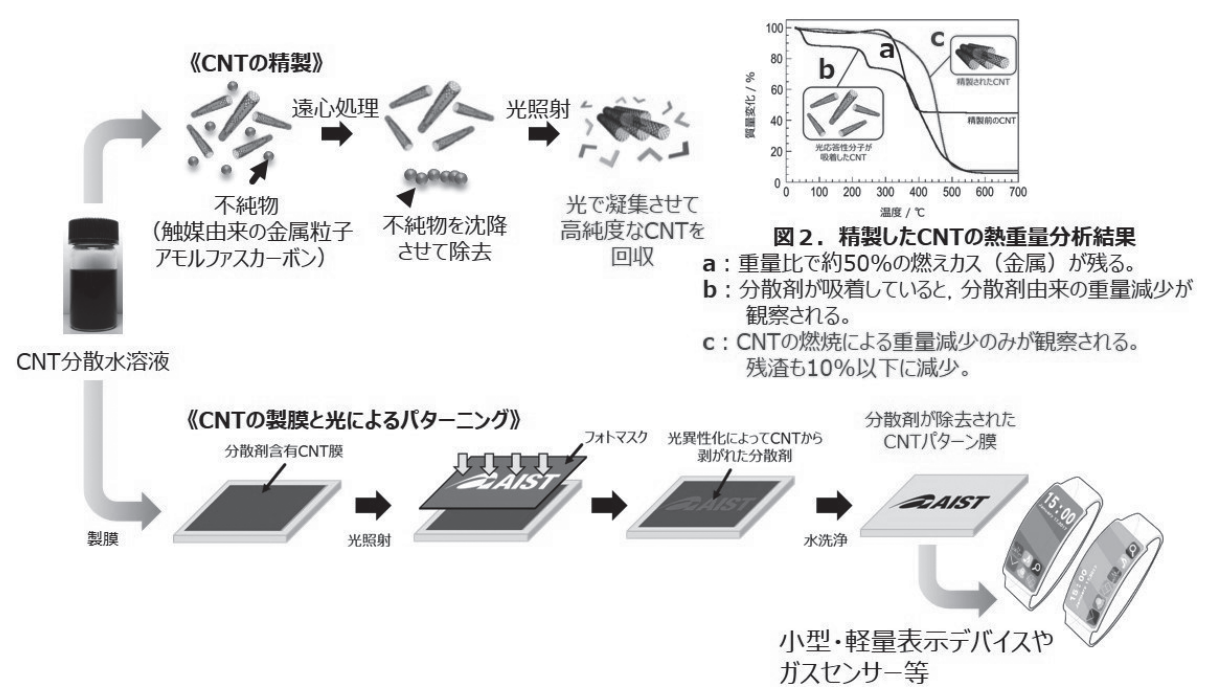

Fig. 4 光応答性分散剤をつかった応用例

い比較評価すると，回収したSWCNT には分散剂由来 の重量減少，金属粒子による残椬が殆ど無く（市販品の 多くは約 $50 \mathrm{wt} \%$ の金属粒子を含んでいることが多い), SWCNT の燃焼による重量現象のみが観察された。さら に，ラマン測定により精製前後のSWCNTに生じた欠 陥の程度を比較したところ，殆ど変化がないことがわ かった。化合物 1 はSWCNT に吸着して孤立分散可能 なため, 超遠心操作によって不純物との分離が充分可能 となり, 最終的に光反応で自発的に剥がれるため, SWCNT の表面を傷めず精製できることがわかった。 SWCNT の純度はSWCNT の物性を左右するため, 強 酸のような過激な条件を必要とせず，温和な条件で精製 できる当該手法は，工業的にも，学術的にも有用である と考えている。

\section{$4 \cdot 2$ 薄膜微細加工 ${ }^{3)}$ (Fig. 4 下)}

この光応答性分散剂は溶液中のみならず，薄膜中でも 光反応が進行する。これを利用すると SWCNT 分散液 を塗布液として作製した薄膜にフォトマスクを介して露 光すると, 露光部と未露光部で SWCNT の水への溶解 性が変えることができる。露光部は光反応した分散剂が 既に分散能を失うために，SWCNT は水に不溶となる。 一方，未露光部は分散剂は分散能を保っているため，製 膜後も水に溶解する。故に，マスク露光後に水で洗浄す ると, 露光部の SWCNT のみが基板に残る（光反応し た分散剂は水に可溶なため, 洗浄液で洗い流すことがで きる）ネガ型のパターン形成が可能なことがわかった。 SWCNT の微細加工には一般的なフォトレジストを使用 する方法等いくつか知られているが，いずれも高価な設 備や，多段階の加工プロセスを必要とする。それに対し て, 本手法は，水系インクを用いて製膜可能な基材に限 定されるが，光と中性水のみという極めて簡易でクリー
ンな手法で微細加工が可能であることが特徵である。

\section{$4 \cdot 3$ 液晶性の発現 ${ }^{4}$}

SWCNT を塗布法でフィルム化するために調製した濃 度の濃い分散液が，液晶相を発現することを見出した。 塗布法で製膜するためには，濃度や粘度が塗布に適した インクを調製する必要がある。フイルム作製用インクは, SWCNT の分散状態を分光評価するために調製する分散 液と比べて濃度を濃くする必要がある。我々はこれまで, 約 $0.03 \mathrm{wt} \%$ に調整した SWCNT 分散液を用いて分光評 価を行ってきたが，塗布法，特にバーコーターを用いて SWCNT 薄膜を作製するために，分散手法等を工夫する ことにより, 〜 1 wt \%の SWCNT インクを調製可能な ことを見出した（Fig. 5 （a）上)。この高濃度インクの 一部を偏光顕微鏡で観察すると Fig. 5 (b) 下のように 複屈折がみられ，液晶相を発現していることが示唆され た。液晶相発現には濃度依存性があり, 分光評価用に調 製した薄い分散液（濃度 $0.03 \mathrm{wt} \%$ ）や $1 \mathrm{wt} \%$ の高濃度 分散液には発現せず, $0.55 \mathrm{wt} \%$ 付近においてのみ液晶 相が発現した。このSWCNT インクは，熱ではなく， 濃度に依存して液晶相が発現するリオトロピック液晶性 があることがわかった。

このインクを基板に滴下して適度な力で一方向にシェ アをかけると，SWCNT を配向させることも可能であっ た。偏光顕微鏡写真を Fig. 6 左に示す。試料を面内で回 転させて観察すると, 明るさが周期的に変化し, 視野全 体にSWCNT が一軸配向していることが示唆された。 原子間力顕微鏡 $(\mathrm{AFM})$ で膜の表面モルフォロジー観 察を行うと, SWCNT からなる繊維状の束が一方向に並 んでいる様子が確認された（Fig.6右）。

CNT の物性を有効利用するための加工技術として, 『配向』させる技術も着目されており，配向させること 
(a)

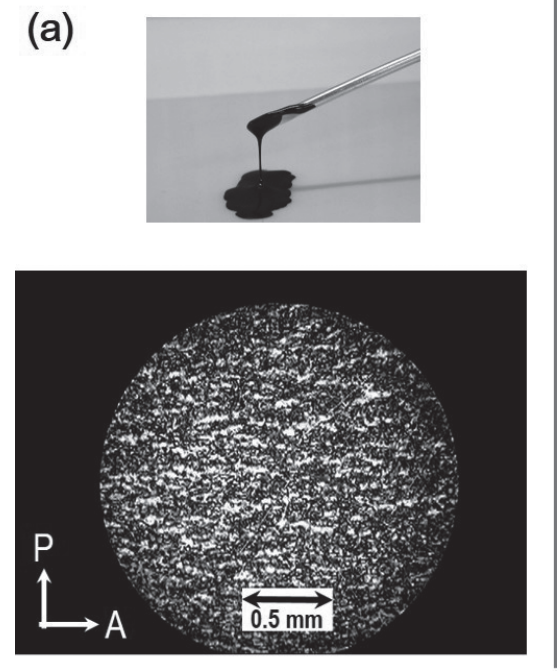

(b)

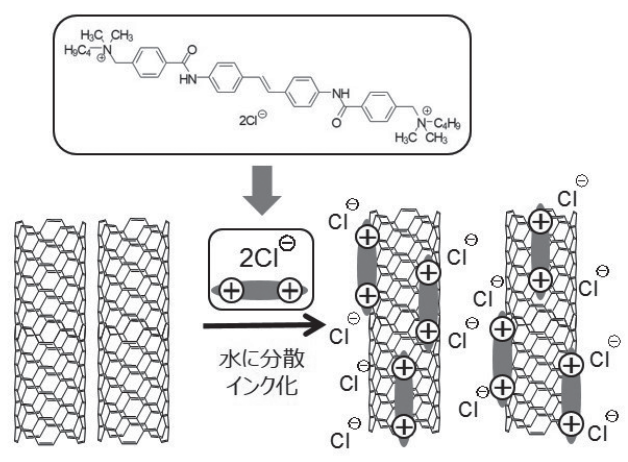

Fig. 5 （a）光応答性分散剂で作製したSWCNT 高濃度インク た液晶相発現メカニズム

（上）とその偏光顕微鏡観察（下）。

(b) SWCNTをメソゲンとし

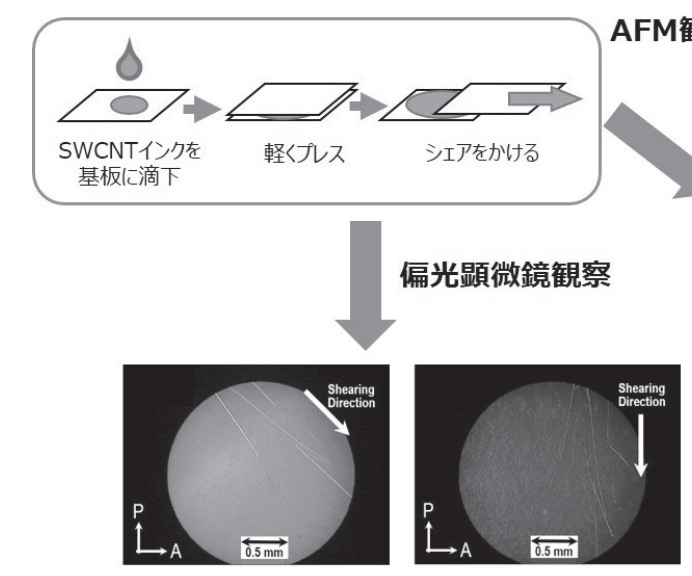

Fig. 6 SWCNT インクの配向性評価
を目的として液晶性 CNT 分散液を作製する研究は, こ れまでにいくつか報告例がある。夕バコモザイクウイル スのように剛直な棒状構造体がメソゲンとなり, 液晶性 を発現するメカニズムを模して，DNAで覆ったり，強 酸や強アルカリでSWCNTの表面を直接処理し, SWCNT 間に静電的な斥力を作用させて液晶性を発現さ せる方法や, 液晶との複合化等が知られている。しかし ながら，これらの方法は配向度が充分でなかったり，表 面処理中にSWCNTに欠陥が生じてしまったり，系中 におけるCNTの成分が少なかったり等の課題があっ た。本手法は, 有機電解質低分子の物理吸着によって SWCNT 表面に正の電荷を発生させ, 液晶性発現の駆動 力としているため (Fig. 5 (b)), 従来法と比較して非常 に温和で簡便に効率よく液晶相を発現させることができ ることが特徵である。配向 SWCNTは, 機械的強度の 向上, 電気特性の向上, そして, テラヘルッ分光用の偏
光素子への応用が期待されており, 我々は今後も引き続 き検討を予定している。

\section{5 光応答性分散剤の市販化}

この光応答性分散剤は，『SWCNTをはじめとするナ ノ炭素材料を効率的に水分散可能で, 光刺激により分散 制御可能な機能性材料』として市販されている。当該化 合物に興味を持っていただいた試薬メーカーより市販化 のお話をいただき，ラボレベルでの合成法を展開して上 市に繋げた（Fig. 7)。写真は, 左から順に合成方法を改 良しつつ試薬メーカーで製造した光応答性分散剤（化合 物 1) である。最初に製造したもの（最左）は，残念な ことに『機能性』が充分発現しなかった。予想だにしな かったことであったが，原因をつきとめ，さらに度重な る改良をすすめ(写真の本数は改良の回数を表す), 最 終製品（最右）に辿りついた。入手いただければ，これ 


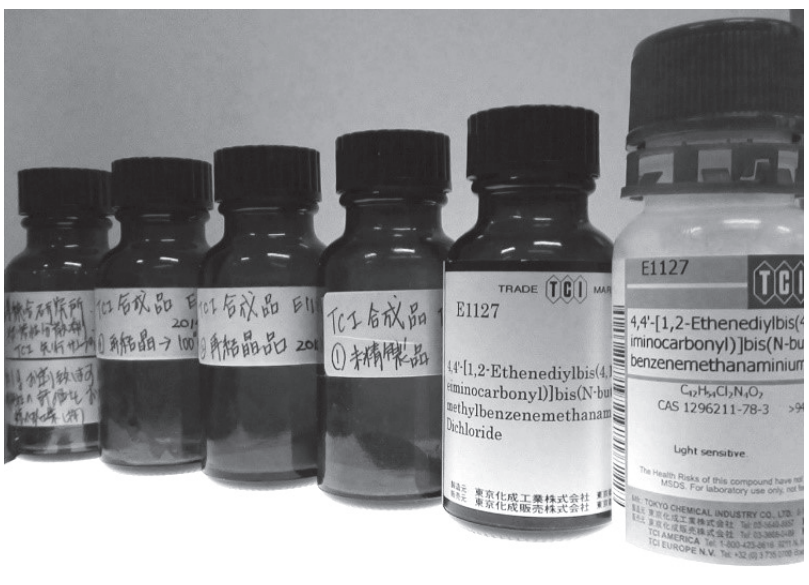

Fig. 7 市販化に向けて試作した光応答性分散剂

までに紹介した『機能』を研究室レベルでどなたでも再 現いただくことができる。

\section{6 おわりに}

ナノ炭素材料, 特にカーボンナノチューブに特化して デザインした光応答性分子を使って, 分子の構造変化に よって物理吸着を制御した，新しい（光）刺激応答性の 分散制御システムを創製した。従来型の界面活性剤とは 似ても似つかない『かたち』をした光応答性分散剂は, 効率的にSWCNT の表面に吸着してその表面物性を劇 的に変え，極性の環境によくなじませることができる。 そして，この分子は光の作用でSWCNT 表面から簡単 に外れ，表面構造を傷めることなく疎水性表面に戻すこ とができる。さらに，分子吸着を利用したSWCNT 表 面の物性制御により, 液晶相発現可能なことも見出し た。最近は，分子設計のさらなる工夫によって，光によ る分散制御が有機溶媒系でも可能となり, なおかつ, 可
逆で高速化もできるようになった ${ }^{5)}$ 。そしてこの高速で 分散制御可能な光応答性分散剂の利用により, 製膜乾燥 工程を必要とせず, 分散液膜に直接光照射することで微 細加工膜を得る手法も確立した ${ }^{6)}$ 。ナノ材料を有効に扱 い，活用していくためには，その表面をよく理解し，制 御することが重要な要素技術となるが，本稿で紹介した 表面物性制御のアプローチが開発のヒントになれば幸い である。

\section{謝辞}

本研究は, 吉田勝博士（産業技総合研究所）との共同 研究です。本研究の一部は, 日本学術振興会科研費基盤 C（22550137 及び JP15K04617）, ならびに国立研究開発 法人科学技術推進機構 A-STEP（AS242Z03940J 及び AS2621398M）の支援によって行われました。

\section{文献}

1) Matsuzawa, Y.; Kato, H.; Ohyama, H.; Nishide, D.; Kataura, H.; Yoshida, M. Adv. Mater. 23, 3922-3925 (2011).

2) Matsuzawa, Y.; Takada, Y.; Kodaira, T.; Kihara, H.; Kataura, H.; Yoshida, M. J. Phys. Chem. C 118, 50135019 (2014).

3) Matsuzawa, Y.; Takada, Y.; Jintoku, H.; Kihara, H.; Yoshida, M. ACS Appl. Mater. Interfaces 8, 28400-28405 (2016).

4) Matsuzawa, Y.; Negoro, C.; Jintoku, H.; Kihara, H.; Yoshida, M. Chem. Lett. 46, 1186-1189 (2017).

5) Jintoku, H.; Matsuzawa, Y.; Kihara, H.; Yoshida, M. Chem. Lett. 45, 1307-1309 (2016).

6) Jintoku, H.; Sato, T.; Nakazumi, T.; Matsuzawa, Y.; Kihara, H.; Yoshida, M. ACS Appl. Mater. Interfaces 9, 30805-30811 (2017). 